\title{
Analisis Taksasi Produksi Tandan Buah Segar Kelapa Sawit dengan Tiga Teknik yang Berbeda di Kebun 1 PT. Tritunggal Sentra Buana
}

\author{
Estimation of Fresh Palm Oil Fruit Production with Three Different Techniques at \\ Garden 1 of PT. Tritunggal Centra Buana \\ M. Fikry Al-Ghozali*, Jamaluddin, Jumri \\ Politeknik Pertanian Negeri Samarinda, Samarinda, Indonesia \\ *Corresponding Author: muhfikry26@gmail.com
}

\begin{abstract}
Abstrak
Penelitian ini bertujuan untuk mengetahui keakuratan data dari beberapa teknik pengambilan sampel untuk taksasi produksi harian pada perkebunan kelapa sawit. Percobaan dilakukan di afdeling 1 TSB 1 dengan sampel utama adalah $10 \%$ dari luas total. Tiga teknik taksasi yang digunakan dalam penelitian ini adalah teknik lurus, teknik segitiga dan teknik segi empat. Selisih tonase dan realisasi yang paling terkecil didapatkan oleh teknik lurus dengan nilai rata-rata sebanyak $209 \mathrm{~kg}$ dan persentase 2,6\%. Sedangkan bahwa jumlah selisih yang paling terbesar adalah teknik segitiga dengan nilai rata-rata sebanyak $2.583 \mathrm{~kg}$ dan persentase $33,5 \%$. Hasil penelitian ini menunjukkan bahwa teknik lurus lebih akurat dan lebih mudah dilakukan daripada teknik segitiga dan teknik segiempat.
\end{abstract}

Katakunci: Taksasi Harian, produksi minyak kelapa sawit

\section{Abstract}

This study aims to determine the data accuracy of several sampling techniques for daily production estimation on oil palm plantations. The experiment was carried out in afdeling 1 TSB 1 with the condition that the main sample was $10 \%$ of the total area. The three taxation techniques used in this study are the straight technique, the triangle technique and the quadrilateral technique. The smallest difference in tonnage and realization was obtained by the straight technique with an average value of $209 \mathrm{~kg}$ and a percentage of $2.6 \%$. Meanwhile, the largest number of differences is the triangle technique with an average value of 2,583 $\mathrm{kg}$ and a percentage of $33.5 \%$. The results of this study indicate that the straight technique is more accurate and easier to do than the triangle technique and the quadrilateral technique.

Keywords: Daily taxation, palm oil production

\section{PENDAHULUAN}

Kelapa sawit merupakan salah satu komoditi sub sektor perkebunan yang dikembangkan dengan skala besar di Indonesia. Kelapa sawit memberi andil besar dalam pemasukan devisa negara diluar sektor minyak dan gas. Oleh karena itu komoditi ini perlu ditingkatkan pengembangannya untuk menunjang program pemerintah dalam upaya mengurangi ketergantungan pada sektor minyak dan gas. Kelapa sawit merupakan sumber minyak nabati yang penting.

Tujuan utama Industri kelapa sawit yang ingin diraih yaitu tercapainya target produksi, produksi merupakan kegiatan yang sangat penting dalam sebuah perusahaan, namun pada pelaksanaannya seringkali produksi tidak tercapai. Agar produksi tercapai perlu dilakukan beberapa tahapan. Tahapan yang dilakukan contohnya yaitu, perawatan tanaman, pemupukan, perbaikan infrastruktur dan pengawasan produksi. Perbaikan infrastruktur juga penting untuk menunjang aktivitas produksi (Mangoensoekarjo \& Semangun, 2008).

Penggunaan minyak kelapa sawit telah dimulai sejak abad ke- 15, sedangkan untuk pemasaran ke Eropa dimulai pada tahun 1800-an. Minyak kelapa sawit yang digunakan berasal dari daging buah (mesocarp) dan dari inti sawit atau kernel (endosperm) (Pahan, 2006). Keadaan jumlah penduduk dunia yang semakin meningkat berdampak pada permintaan CPO (crude palm oil) yang juga meningkat pesat. Untuk memenuhi kebutuhan tersebut beberapa negara terutama Indonesia meningkatkan produksi kelapa sawit melalui perluasan perkebunan kelapa sawit di seluruh wilayah Indonesia.

Menurut data dari pusat kenaikan luas lahan dari dari 8 juta ha pada tahun 2010 
menjadi 10 juta ha pada tahun 2012, sedangkan produksi CPO 19 ton pada tahun 2010 dan mengalami kenaikan menjadi 26 ton pada tahun 2012. Dari data diatas luas lahan dan jumlah produksi kelapa sawit semakin meningkat setiap tahunnya. Setiap tahunnya perkebunan kelapa sawit semakin luas dengan banyaknya pembukaan lahan kelapa sawit. Dalam beberapa tahun ke depan pemerintah berencana untuk memperluas perkebunan kelapa sawit dengan target produksi pada tahun 2020 mencapai 52 juta ton per tahun. Salah satu alasan untuk memperluas perkebunan dan produksi kelapa sawit karena prediksi peningkatan permintaan khususnya di pasar internasional atas minyak nabati dari kelapa sawit, yang bukan hanya dimanfaatkan untuk kebutuhan industri pangan dan industri kosmetik seperti selama ini, namun telah meluas untuk kebutuhan energi. Untuk memenuhi target produksi sebesar itu, maka pemerintah dengan gencar melakukan pembukaan areal-areal perkebunan baru, termasuk di daerah yang selama ini tidak pernah menanam sawit seperti di Sulawesi dan Papua.

Produktivitas tanaman kelapa sawit dipengaruhi oleh faktor internal dan eksternal. Faktor internal berasal dari dalam tanaman itu sendiri, misalnya kualitas biji yang tidak baik, biji dorman. Faktor eksternal berasal dari lingkungan, antara lain curah hujan, iklim, kondisi tanah, dan faktor pemeliharaan atau budidaya. Buah kelapa sawit pada tiap areal panen dapat dibagi menjadi 3 atau 4 hari panen dengan rotasi tetap 7 hari. dalam keadaan normal, panen dilakukan 6 kali dalam seminggu, yaitu senin sampai sabtu atau disebut sistem panen 6/7.

Taksasi dilakukan untuk memperkirakan biaya produksi dan pendapatan pada panen yang akan datang dan juga untuk memperkirakan biaya produksi dan memperkirakan produktivitas tanaman kelapa sawit yang akan datang. Taksasi adalah suatu bentuk peramalan produksi tanaman kelapa sawit yang didasarkan pada umur tanaman sesuai dengan kelas wilayahnya. Taksasi berhubungan perhitungan biaya produksi dan pendapatan yang akan datang, sehingga mempengaruhi sistem usaha perkebunan kelapa sawit di areal tersebut. Taksasi dilakukan untuk memperkirakan biaya produksi dan pendapatan pada panen yang akan datang dan juga untuk memperkirakan produksi tanaman kelapa sawit. Taksasi bisa dilakukan secara 6 bulan, 3 bulan, 1 bulan, dan harian. Setiap perusahaan selalu melakukan kegiatan taksasi, tetapi kebijakan yang dikeluarkan setiap perusahaan berbeda-beda.

Berdasarkan latar belakang diatas, peneliti ingin meneliti tentang perbedaan tingkat akurasi dari beberapa teknik taksasi yaitu teknik lurus, teknik segitiga dan teknik segiempat.

\section{METODE PENELITIAN}

\section{A. Waktu dan Tempat Penelitian}

Penelitian ini dilaksanakan di PT. Tri Tunggal Sentra Buana Desa Saliki, Kecamatan Muara Badak, Kabupaten Kutai Kartanegara, Provinsi Kalimantan Timur. Terihitung dari bulan September sampai dengan bulan Desember.

\section{B. Alat dan Bahan}

Alat yang digunakan pada penelitian ini yaitu alat buku atau form Angka Kerapatan Panen (AKP) dan bolpoin. Adapun bahan yang digunakan yaitu tanaman kelapa sawit yang sudah produksi/panen.

\section{Metode Pengambilan Data}

Pengumpulan data adalah teknik atau cara yang dilakukan untuk mengumpulkan data. Pengumpulan data adalah proses mengumpulkan dan mengukur informasi tentang variabel penelitian yang diminati, dengan cara sistematis yang memungkinkan seseorang untuk menjawab pertanyaan penelitian yang dinyatakan menguji hipotesis dan mengevaluasi hasil. Adapun teknik pengambilan data yang peniliti pakai untuk penelitian ini yaitu :

\section{Obesrvasi}

Metode pengumpulan data yang kompleks karena melibatkan berbagai faktor dalam pelaksanaannya. Metode pengumpulan data observasi tidak hanya mengukur sikap responden, namun juga dapat digunakan untuk merekam berbagai fenomena yang terjadi. Metode obeservasi merupakan aktivitas penelitian dalam rangka mengumpulkan data berkaitan dengan masalah penelitian melalui proses pengamatan langsung ke lapangan. 


\section{Studi Pustaka}

Studi pustaka, menurut Nazir (2003,) teknik pengumpulan data dengan mengadakan studi penelaah terhadap bukubuku, literatur-literatur, catatan-catatan, dan laporan-laporan yang ada hubungannya dengan masalah yang dipecahkan.

3. Sumber Data

Data yang digunakan dalam penelitian ini berdasarkan sumbernya dibedakan menjadi 2 yaitu sumber data primer dan sekunder.

\section{Prosedur Kerja}

1. Pesiapan

Menentukan blok yang akan diteliti dengan syarat luas blok yang sama, umur tanaman yang sama dan varietas yang sama. Taksasi dari tiga metode tersebut akan diperoleh jumlah pokok yang akan dipanen yang selanjutnya digunakan untuk menghitung Angka Kerapatan Panen (AKP).

\section{Perlakuan}

\section{a. Menentukan Pokok Sampel}

Dalam menentukan pokok sampel yang akan diteliti, pada setiap blok diambil pokok sampel sebanyak $10 \%$ dari total pokok pokok pada setiap bloknya.

1) Teknik Taksasi Lurus

Jenis taksasi yang mengambil sampel pokok sebanyak $10 \%$ pada blok yang telah ditentukan, dimulai dari baris tanam ke $5,10,20,30,40,50$ dan seterusnya. Mandor panen tidak hanya mencatat buah matang hanya pada pokok pertama akan tetapi mandor mengikuti pasar pikul pada baris pokok yang telah ditentukan. Mandor panen mencatat buah matang yang ada di pokok sawit dengan syarat sudah ada yang memberondol dari tandan jatuh ke piringan (Hanif Suhron Nur Fais,Tri Nugraha Budi Santosa, Samsuri Tarmadja 2016).

2) Teknik Taksasi Sigitiga

Teknik pengambilan taksasi segitiga yaitu menentukan blok dengan sampel $10 \%$ yang akan diteliti untuk tiga kali ulangan pada 1 afdeling. Menentukan baris tanaman pada baris $1,2,3,4,5,6$ dan seterusnya mengamati buah yang sudah matang dengan syarat buah sudah memberondol (Hanif Suhron Nur Fais,Tri Nugraha Budi Santosa, Samsuri Tarmadja 2016).

3) Teknik Taksasi Segiempat

Teknik pengambilan taksasi segi empat yaitu menentukan blok dengan sampel pokok
$10 \%$ yang akan diteliti untuk tiga kali ulangan pada 1 afdeling. Menentukan baris pokok pada baris ke $1-6,16-21$ dan 31 - 36 dengan mengamati buah yang sudah matang dengan syarat buah sudah memberondol (Hanif Suhron Nur Fais,Tri Nugraha Budi Santosa, Samsuri Tarmadja 2016).

b. Menentukan Berat Janjang Rata-rata (BJR)

Berat janjang rata-rata biasanya sudah ditentukan oleh perusahaan tersebut.

c. Menentukan Angka Kerapatan Panen (AKP)

Untuk mencari AKP dalam bentuk panen yaitu jumlah janjang taksasi dibagi jumlah pokok sampel yang kemudian dikalikan $100 \%$.

d. Menentukan Jumlah Janjang Taksasi

Untuk menentukan jumlah janjang taksasi yaitu dengan mengamati langsung buah matang pada pokok yang siap dipanen esok hari.

\section{E. Analisis Data}

Analisis data adalah proses pengolahan data dengan tujuan untuk menemukan informasi yang berguna dapat dijadikan dasar dalam pengambilan keputusan pada suatu permasalahan. Menurut Sugiyono (2010 : 335) analisis data adalah proses mencari data, menyusun data secara sistematis dari data yang diperoleh dari hasil wawancara, catatan lapangan dan dokumentasi. Dengan cara mengorganisasikan data kedalam kategori, menjabarkan kedalam unit-unit, melakukan sintesis, menyusun kedalam pola memilih mana yang penting dan mana yang akan dipelajari dan membuat kesimpulan sehingga mudah dipahami diri sendiri maupun orang lain.

Dari data yang sudah didapat tersebut adalah data taksasi tanggal 26 November 2020. Data dianalisis dengan melihat indikator utama dalam taksasi, Analisis yang digunakan untuk mengolah data yang diperoleh dari kegiatan taksasi adalah teknik analisis kualitatif dengan perhitungan sederhana menggunakan Microsoft Excel untuk melihat tingkat akurasi dan perbedaan hasil taksasi dan realisasi yang mana berupa jumlah janjang, selisih janjang dan selisih tonase dilihat dari yang mendekati angka 
realisasi. Setelah didapatkan perbedaan dari taksasi tiga teknik dengan realisasi tersebut kemudian diuraikan secara deskriptif.

\section{HASIL DAN PEMBAHASAN}

Hasil analisis keakuratan teknik taksasi harian ini dilakukan di PT. Tri Tunggal Sentra Buana untuk membandingkan jenis teknik taksasi yang paling mendekati dengan realisasi. dengan mengambil $10 \%$ pokok sampel pada setiap blok untuk diamati buah yang siap panen esok hari, peneliti melakukan sebanyak 3 kali ulangan dengan teknik yang sama pada blok yang berbeda yaitu dengan syarat tahun tanam yang sama, luas lahan yang sama. Hasil pengamatan nilai Angka Kerapatan Panen (AKP) dengan menggunakan teknik lurus, teknik segitiga dan teknik segiempat pada Tabel 1. Adapun data realisasi janjang dan tonase dapat dilihat pada Tabel 2. Data realisasi janjang didapatkan dari data panen kerani afdeling dan angka realisasi tonase diperoleh dari penimbangan pada saat pengangkutan ke pabrik kelapa sawit.

Tabel 1. Taksasi Harian Menggunakan Tiga Teknik

\begin{tabular}{ccccccccc}
\hline \multirow{2}{*}{ Teknik } & Blok & Ulangan & $\begin{array}{c}\text { Pokok } \\
\text { Sampel }\end{array}$ & $\begin{array}{c}\text { Janjang } \\
\text { Diamati }\end{array}$ & AKP & BJR & \multicolumn{2}{c}{ Hasil Taksasi } \\
\hline \multirow{3}{*}{ Lurus } & A06 & Satu & 195 & 43 & $22 \%$ & 15,98 & 428 & 6839 \\
\cline { 2 - 9 } & A07 & Dua & 271 & 59 & $21 \%$ & 13,57 & 597 & 8101 \\
\cline { 2 - 9 } & A08 & Tiga & 270 & 43 & $15 \%$ & 16,23 & 404 & 6557 \\
\hline \multirow{3}{*}{ Segitiga } & A06 & Satu & 195 & 29 & $15 \%$ & 15.98 & 291 & 4650 \\
\cline { 2 - 9 } & A07 & Dua & 271 & 30 & $11 \%$ & 13,57 & 298 & 4044 \\
\cline { 2 - 9 } & A08 & Tiga & 270 & 35 & $13 \%$ & 16,23 & 350 & 5681 \\
\hline \multirow{3}{*}{ Segiempanen } & A06 & Satu & 195 & 37 & $19 \%$ & 15,98 & 369 & 5896 \\
\cline { 2 - 9 } & A07 & Dua & 271 & 49 & $18 \%$ & 13,57 & 489 & 6636 \\
\cline { 2 - 9 } & A08 & Tiga & 270 & 54 & $20 \%$ & 16,23 & 539 & 8748 \\
\hline
\end{tabular}

Tabel 2. Realisasi Janjang dan Tonase

\begin{tabular}{cccccc}
\hline \multirow{2}{*}{ No Blok } & Luas & \multicolumn{4}{c}{ Realisasi } \\
\cline { 3 - 6 } & & $\begin{array}{c}\text { Pokok } \\
\text { Produktif }\end{array}$ & BJR & Janjang & Tonase \\
\hline A 06 & 14 & 1.950 & 15,98 & 496 & 6.735 \\
\hline A 07 & 19 & 2.711 & 13,57 & 617 & 8.563 \\
\hline A 08 & 19 & 2.696 & 16,23 & 511 & 6.826 \\
\hline
\end{tabular}

\section{Selisih Taksasi dan Realisasi}

Ada 2 jenis selisih yang harus diketahui peneliti yaitu :

\section{a. Selisih Janjang}

Selisih janjang ini didapatkan dari pengurangan antara jumlah janjang realisasi dan taksasi sehingga didapatkan selisih janjang kemudian di persentasekan. Adapun rumus untuk menghitung persen pada selisih janjnag yaitu jumlah selisih dibagi jumlah janjang realisasi dan dikalikan seratus persen.

$$
\% \text { selisih janjang }=\frac{\text { selisih }}{\text { realisasi }} X 100 \%
$$

\section{b. Selisih Tonase}

Selisah tonase ini didapatkan dari pengurangan antara tonase janjang realisasi dan taksasi yang kemudian persentasekan. Adapun hasil selisih janjang dan tonase taksasi dari menggunakan tiga teknik tersebut dan tonase realisasi dapat dilihat pada Tabel 3.

Perbedaan hasil dalam estimasi dan realisasi dapat disebabkan oleh tingkat 
ketelitian saat pengamatan masih rendah atau adanya kesalahan dari pemanen itu sendiri baik pemanenan tandan yang belum memenuhi kriteria atau buah matang tertinggal di tanaman, Miranda (2009).

Tabel 3. Selisih Taksasi dan Realisasi Blok A06, A07 dan A08

\begin{tabular}{|c|c|c|c|c|c|c|c|c|c|}
\hline \multirow{2}{*}{ Teknik } & \multirow{2}{*}{ BLOK } & \multicolumn{3}{|c|}{ Janjang } & \multirow{2}{*}{$\begin{array}{c}\text { Persentase } \\
\text { (\%) }\end{array}$} & \multicolumn{3}{|c|}{ Tonase } & \multirow{2}{*}{$\begin{array}{c}\text { Persentase } \\
\text { (\%) }\end{array}$} \\
\hline & & Taksasi & Realisasi & Selisih & & Taksasi & Realisasi & Selisih & \\
\hline \multirow{3}{*}{ Lurus } & A06 & 428 & 496 & 68 & 0,14 & 6839 & 6.735 & -104 & $-1,5$ \\
\hline & A07 & 597 & 617 & 20 & 0,03 & 8101 & 8.563 & 462 & 5,4 \\
\hline & A08 & 404 & 511 & 107 & 0,21 & 6557 & 6.826 & 269 & 3,9 \\
\hline \multicolumn{2}{|c|}{ Rata-rata } & & & & 0,13 & & & & 2,6 \\
\hline \multirow{3}{*}{ Segitiga } & A06 & 291 & 496 & 205 & 0,41 & 4650 & 6.735 & 2.085 & 31,0 \\
\hline & A07 & 298 & 617 & 319 & 0,52 & 4044 & 8.563 & 4.519 & 52,8 \\
\hline & A08 & 350 & 511 & 161 & 0,32 & 5681 & 6.826 & 1.145 & 16,8 \\
\hline \multicolumn{2}{|c|}{ Rata-rata } & & & & 0,42 & & & & 33,53 \\
\hline \multirow{3}{*}{$\begin{array}{l}\text { Segi- } \\
\text { empat }\end{array}$} & A06 & 369 & 496 & 127 & 0,26 & 5896 & 6.735 & 839 & 12,5 \\
\hline & A07 & 489 & 617 & 128 & 0,21 & 6636 & 8.563 & 1.927 & 22,5 \\
\hline & A08 & 539 & 511 & -28 & $-0,05$ & 8748 & 6.826 & -1.922 & $-28,2$ \\
\hline \multicolumn{2}{|c|}{ Rata-rata } & & & & 0,14 & & & & 2,3 \\
\hline
\end{tabular}

Perbedaan hasil dalam estimasi dan realisasi dapat disebabkan oleh tingkat ketelitian saat pengamatan masih rendah atau adanya kesalahan dari pemanen itu sendiri baik pemanenan tandan yang belum memenuhi kriteria atau buah matang tertinggal di tanaman, Miranda (2009).

1. Taksasi Harian

Dilihat dari tabel 2 pengambilan taksasi harian dengan menggunakan tiga teknik yaitu teknik lurus, segitiga dan segiempat dengan pengambilan sampel $10 \%$ dari luasan kebun. Untuk pengambilan angka kerapatan panen menggunkan teknik lurus diambil dari baris pokok $5,10,30,40,50$ dan seterusnya.

Sedangkan untuk pengambilan angka kerapatan panen dari teknik segitiga diambil dari pokok 1,2,3,4,5,6 dan setrusnya. Kemudian untuk pengambilan angka kerapatan panen teknik segiempat dimulai dari pokok 1 - 6, $16-21,31$ - 36 dan seterusnya. Dari hasil pada tabel 2 dapat diketahui teknik lurus nilai Angka Kerapatan Panen (AKP) berkisar $15 \%$ - 22\% pada tiga kali ulangan untuk di blok yang berbeda sedangkan untuk teknik segitiga nilai angka kerapatan panen berkisar di 11\% - 15\% dengan tiga kali ulangan di blok yang berbeda dan untuk teknik segiempat nilai angka kerapatan panen berkisar di 18\% $20 \%$ dengan tiga kali ulangan di blok yang berbeda.

2. Selisih Janjang Taksasi dan Realisasi Nilai angka realisasi janjang didapat dari kerani afdeling setelah dilakukannya kegiatan panen Tandan Buah Segar (TBS). Dilihat dari tabel 3 hasil selisih janjang taksasi dan realisasi yang paling terkecil didapatkan oleh teknik lurus dengan nilai rata-rata sebanyak $0,13 \%$. Sedangkan pada hasil selisih janjang taksasi dan realisasi yang paling terbesar didapatkan oleh teknik segitiga yang mana nilai rata-rata diperoleh sebanyak $0,42 \%$ dan 
hasil selisih janjang teknik segiempat yang didapatkan yaitu $0,14 \%$.

Ada beberapa faktor kenapa terjadi selisih janjang yang masih tergolong cukup tinggi pada teknik lurus, seperti adanya pemanen yang tidak bisa menyelesaikan hancanya pada saat melakukan kegiatan pemanenan dan ada kemungkinan buah mentah atau buah tinggal di pokok. Sedangkan pada teknik segitiga percobaan dilihat dari data aktual janjang yang dipanen dibandingkan dengan taksasi teknik segitiga didapatkan selisih yang sangat jauh. Kemudian pada teknik segiempat percobaan didapatkan hasil selisih yang lumayan tinggi dikarenakan kemungkinan terdapat buah tinggal atau buah mentah pada blok yang di taksasi.

3. Selisih Tonase Taksasi dan Realisasi.

Nilai angka realisasi tonase didapat dapat dari penimbangan pada saat pengangkutan Tandan Buah Segar (TBS) di pabrik kelapa sawit. Dilihat dari tabel 3 hasil selisih tonase dan realisasi yang paling terkecil didapatkan oleh teknik lurus dengan nilai rata-rata sebanyak $209 \mathrm{~kg}$ dan persentase 2,6 \%. Sedangkan bahwa jumlah selisih yang paling terbesar adalah teknik segitiga dengan nilai rata-rata sebanyak $2.583 \mathrm{~kg}$ dan persentase $33,5 \%$. hasil selisih tonase teknik taksasi segiempat dan realisasi yang didapatkan dengan nilai rat-rata adalah $281 \mathrm{~kg}$ dan persentase 2,3\%. Selisih yang terjadi pada taksasi teknik lurus masih batas toleransi karena kurang lebih dari $5 \%$, sedangkan selisih dari taksasi teknik segitiga sudah melebihi dari $5 \%$ dan tidak dianjurkan.

\section{Taksasi Teknik Lurus}

Adapun kelebihan dan kekurangan pada saat peneliti melakukan sensus dan pengamatan menggunakan taksasi teknik lurus yaitu :

\section{a. Kelebihan}

Memudahkan mandor saat melakukan taksasi harian tidak memakan banyak waktu, jalur sensus mudah dilewati dan bisa dilakukan di lahan terasan.

b. Kekurangan

Pengamatan janjang panen tidak bisa dilakukan di gawangan saja akan tetapi peneliti atau mandor panen harus mengelilingi pokok tersebut sehingga ditentukan berepa janjang yang akan dipanen esok hari.

\section{Taksasi Teknik Segitiga}

Adapun kelebihan dan kekurangan pada saat peneliti melakukan sensus dan pengamatan taksasi teknik segitiga yaitu:

a. Kelebihan

Pengambilan taksasi harian karena hanya mengikuti pola segitiga yang sudah ditetapkan dan juga pokok sampel yang diambil cuma hanya satu baris.

b. Kekurangan

Jalan yang susah dilewati karena jalur yang dilewati kebenyakan gawangan mati dan pokok yang ditengah dari pola segitiga tidak diambil sampel tingginya resiko kecelakaan kerja dan tidak memungkinkan dilakukan pada terasan.

6. Taksasi Teknik Segiempat

Adapun kelebihan dan kekurangan pada saat peneliti melakukan sensus dan pengamatan taksasi teknik lurus yaitu :

a. Kelebihan

Mempercepat pengambilan sensus angka kerapatan panen karena hanya mengambil pokok pada pinggiran blok pada pola segi empat yang sudah ditetapkan.

b. Kekurangan

Saat pengambilan sensus angka kerapatan panen teknik ini tidak dapat dilakukan pada kondisi lahan terasan dan sebagian pokok sampel melewati gawangan mati sehingga menyusahkan saat sensus.

\section{KESIMPULAN}

Berdasarkan hasil penelitian yang didapatkan untuk mengetahui perbandingan antara taksasi dengan realisasi pengambilan angka kerapatan panen menggunakan tiga pola yaitu teknik lurus, teknik segitiga percobaan, dan teknik segiempat percobaan pada perusahaan di PT. Tri Tunggal Sentra Buana 1 afdeling 1, maka dapat disimpulkan oleh peneliti bahwa, hasil rata-rata selisih (\%) janjang taksasi dan realisasi dalam bentuk persen yaitu realisasi dan lurus sebesar $0,13 \%$. Hasil rata-rata tonase yang didapat dari taksasi di lapangan dengan ketiga jenis teknik tersebut yaitu teknik lurus sebesar 209 $\mathrm{kg}$. Jadi taksasi teknik lurus yang paling mendekati angka realisasi karena jalur yang dilewati cukup mudah dan janjang panen yang didapatkan akurat. 


\section{DAFTAR PUSTAKA}

Akiyat. 2002. Budidaya Kelapa Sawit. Pusat Penelitian Kelapa Sawit. Medan.

Anonim, 1996. Pedoman brevert dasar-II tanaman kelapa sawit. Astra Agro Niaga

Anonim, 2004. Kultur Teknis Kelapa Sawit. Pusat Penelitian Kelapa Sawit, Medan

Buana, L., D. Siahaan, dan S.Adiputra. 2003. Kultur Teknis Kelapa Sawit. Pusat Penelitian Kelapa Sawit. Medan, Sumatera Utara.

Darmadi, Hamid. 2014. Metode Penelitian Pendidikan Sosial. Bandung

Hakim Memet. 2013. Kelapa Sawit Teknis Agronomi dan Manajemennya Tinjauan Teoritis dan Praktis Media perkebunan. Jakarta.

Hanif Suhron Nur Fais, Tri Nugraha Budi Santosa, Samsuri Tarmadja. 2016. "Akurasi Beberapa Teknik Sampling Dalam Taksasi Produksi Kelapa Sawit". Jurnal Agromast. Vol.1, No. 2.

Mangoensoekarjo, S. dan H. Semangun. 2003,2008. Manajemen Agrobisnis Kelapa Sawit. Gadjah Mada University Press. Jakarta.

Miranda, R.R. 2009. Manajemen panen tanaman kelapa sawit (Elaeis guineensis Jacq.) di PT. Gunung Kemasan Estate, Minamas Plantation, Pulau Laut, Kalimantan Selatan (Skripsi). Institut Pertanian Bogor. Bogor.

Muhammad Irfan Miraza, Memen Surahman. 2015. "Hubungan Angka Kerapatan Panen dan Sistem Rotasi Panen Dengan Produktivitas Kelapa Sawit (Elaeis guineensis Jacq)". Sumatera Utara. Bul. Agrohorti. 3(1): $59-64$

Naiboho, P.M. 1996. Teknologi Pengolahan Kelapa sawit. Pusat Penelitian Kelapa Sawit. Medan. 